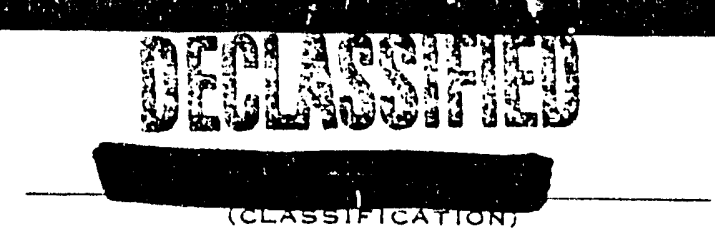

$\mathrm{HW}--65733-\mathrm{RD}$

DE93 003526

\title{
GENERAL ELCTRIC
}

HANFORD ATOMIC PRODUCTS OPERATION - RICHLAND, WASHINGTON

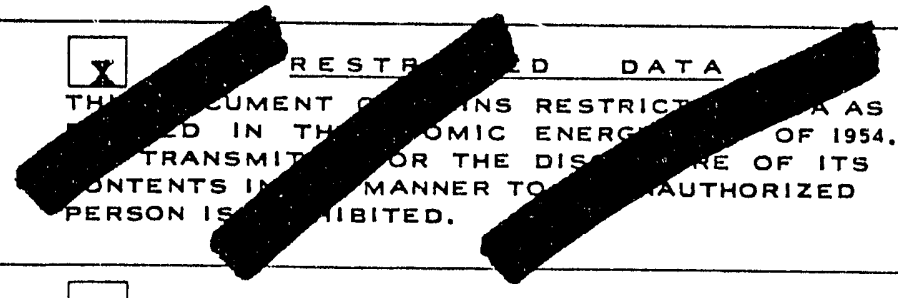

OTHER OFFICIAL CLASSIFIED INFORMATION

THIS MATERIAL CONTAINS INFORMATION AFFECTING THE NATIONAL DEFENSE OF THE UNITED STATES WITHIN THE MEANING OF THE ESPIONAGE LAWS, TITLE 18, U.S.C., SECS. 793 AND 794, THE TRANSMISSION OR REVELATION OF WHICH IN ANY MANNER TO AN UNAUTHORIZED PERSON IS PROHIBITED BY LAW.

TITLE

Norember 17,1959

HASITS DISPOSAL CRTIMSRA SXISTIIG REACTOR EXPANSTON STUDY

AUTHOR

R. B. HaII
CISGUNA
RECEIVED JUN23 1960 REIURN TO TECHNICAL INSARMATIONLEUES

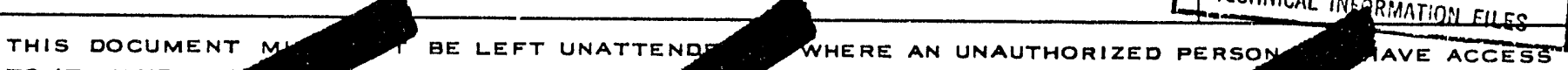
TO IT. WHEN NP SE, IT MUST BE STORE GUARDED AF? TLE IT IS IN YOUR POSSF CLASSIFY CES, IT IS YOUR RESPO THIS CT AND FROM ANY UNAUTHO OF DENCE IS PROHIBITED. - THEM FROM THE RELATE IGN IN THE SPACE PROVIDE LOW. UINT TO BE DUPLICATED. IF MILNAL COPIES ARE REQUIRED, AN APPROVED LOCKED REPOSITORY AND UNTIL YOU HAVE OBTAIN? M AND UNTIL YOU HAVE OBTAINY TO KEEP IT AND ITS CON
LITY D PERSON. ITS TRANSMITTAL MN AN APPROVED WITHIN THE LIMITS OF NO STORAGE AT YOUR PLACE THONAL COPIES ARE REQUIRED,

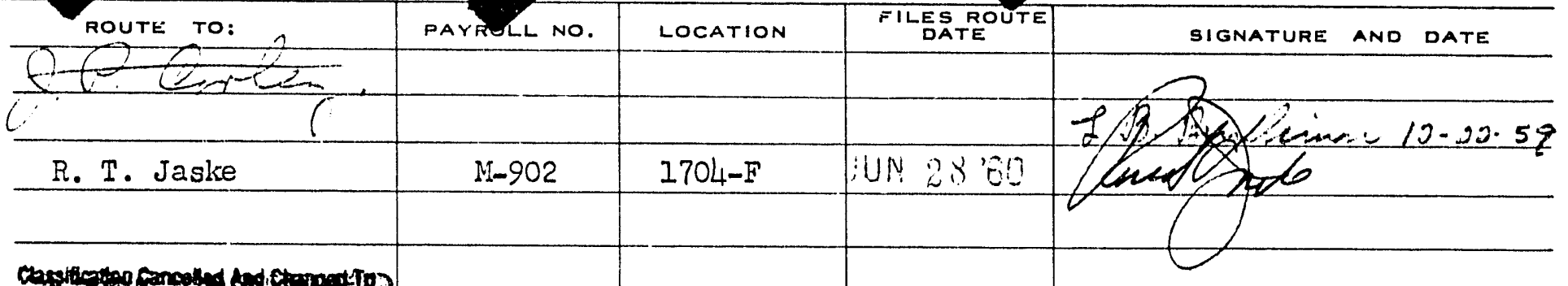

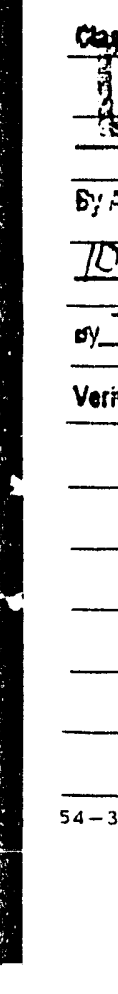

政

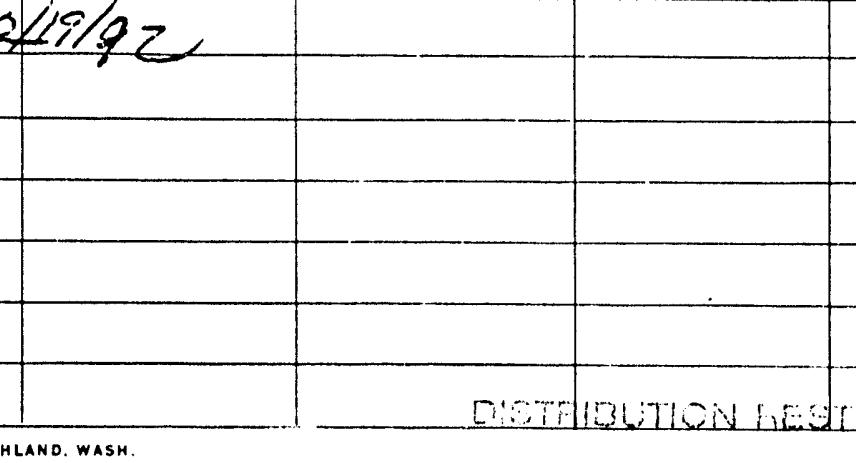

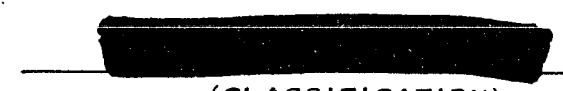

(CLASSIFICATION) 


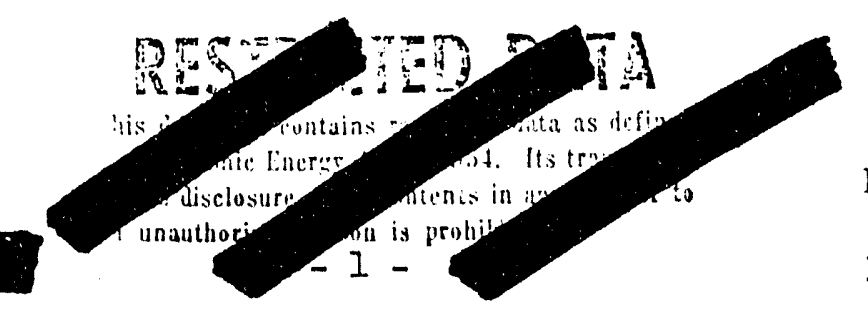

H:I-65732 RD

WASIM DISPOSAL CRITIRRTA

EXISTINV REACTOR EXPAISTON SIUDY

SUMANY

November 17, 1959

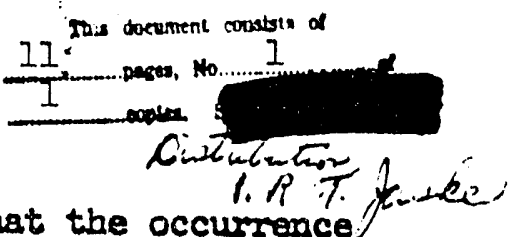

Waste Alsposal criterla vere established an the basis that the occurrence. of Irver flow rates which were $72, y$ of normal would not cause the effects of waste disposal to exceed IImits. SInce even the base case exceeds the criterton for the average body burden of phosphorus-32, provision to reduce the output of thls rediolsotope must be 1ncluded in any expansion program. Provision to reduce the output of other rediolsotopes wlll be required for most csses where the bulk outlet temperature limft is $105^{\circ}$ or higher. For reactor flow rates exceeding 100,000 gom it may be necessary to reduce sodium dichromate concentrations as Low as 1.5 ppa during perlods of low rlver flow. Heat cutput was discussed but no limit was set.

I. CRIIERTA

A. Modirlcations shall be oo desloned that radiolsotopes which are discharged to the river or which reach the river after discharge of vastes to the sall can be controlled durlag a year when the wher flow rate is normal ouch that:

1. The comblned effects of the radionuclldes Introduced from all reactors would result in an annual average concentration of radionuclides in the Fiver at Pasco of no more than $3.6 \%$ MPC*.

2. The comblned effects of the radsomulides introduced from all reactors would regult in an annual average concentration of radionuclides in the drlaktng water at any reactor area of no more than $7.2 \%$ MPC".

*MPC-Maxdram Permissible Concentration of radiolsotopes in drinking water. The values referred to are those for continuous occupational exposure as: stated in Appendix A of the Radiation Protection Standards (HW-25457 Rev. 1). 


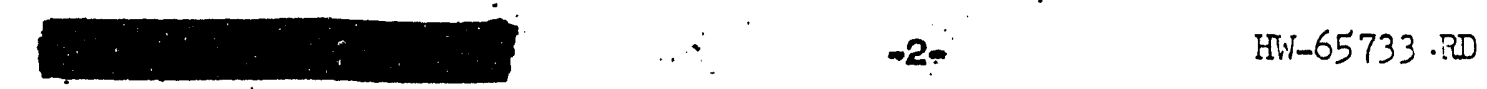

3. It would be improbable that the anmual average body burden of phosphorus-32 for any 1ndividual would exceed 0.36 mfcrocurles.... :

B. The release of bexsvalent chromtum Ion to the 11 ver shall be so controlled that the concentration in drinlatis water w1ll not exceed $0.05 \mathrm{ppm}$ and the monthly arerage cancentration in fiver water wil not exceed $0.02 \mathrm{ppm}$.

C. Reesonable effort to 21mt the increase of Ifrex temperature due to the operation of the reactors dursing Auguat and September is recommended. However, the present technical bas1s w1II not support the eatablishment of a limt on the amount of heat that may be added.

II. BASES

The criterion for the release of radiolsotopes to the river was based on Padiation Protection Standards 3.1 and 7.2 , on the assingtion that river 1low rates $72 \%$ of normal could be expected uth reasonable frequency and on the premlse that IImfts should not be exceeded when this low flow rate extsts.

The criterion for the release of bexavelent chromium was besed on a Publlc Bealth Servlce Water Standard and on recomendations of the Aquatic Blolosy Operation. The Publlo Health Service Water Standard, whlch is followed at HAPO, states "hexavalent chromium in excess of 0.05 ppm shall constitute grounds for rejection of the supply." Ihis 18 Interpreted by Industrial Fyefene to mean that 0.05 ppm hexavalent chromium shall be the maxdmom accpetoble ior drinking vater at any time. (I) R. F. Foster estab-

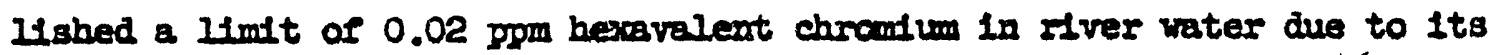

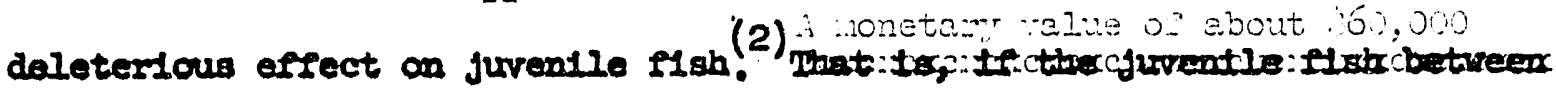

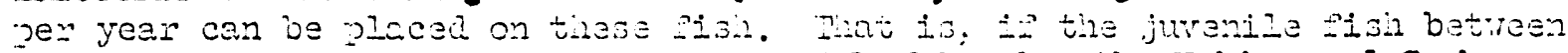

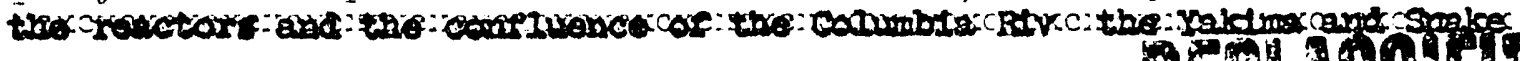

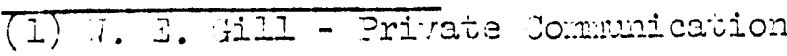

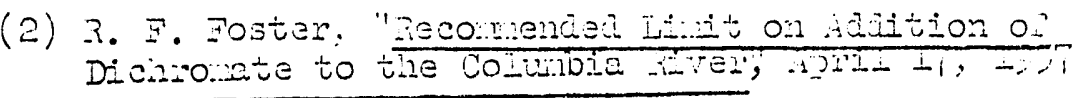
(1)

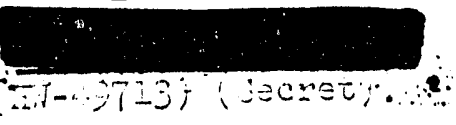


HW-65733-RD

the reactors and the confluence of the Columble vith the Yakelma and srake Fivers vero destroyed, the commeretal slahing Induotry might ouffer an anmel $108 \mathrm{~s}$ of about $\$ 60,000$. Thts valise cannot be considered r1rm, but is quoted in order to give a basts for judgement.

The criterton for the release of heat is based on the optution of the Blalos; Operation that temperatures over $20^{\circ} \mathrm{C}$ at Bonneville Dam could result in epidemic disease among salmon. (3) The usual bigh temperature pertod occurs in late Auguat and eariy Beptember whlch colnctdes with the time that a large nun of Chinock salmce are in the river. The value of thls particular salmon rum has been estlmated to be $\$ 5,000,000$ anmally. Agatn the sccuracy of this number is not guaranteed, but it is included to permet judgement of the problem.

\section{BFEECIS OF REACIOR EXPAISTION}

\section{A. General}

The criterion for phoophorus-32 is being exceedat at this time and it is expected that the operation of Priest Raptds Dam way cause the criterion for hesavalent chromtum in dxinking water to bo exceeded durlag a vinter when asghttime flow rates are recuced to 36,000 cfs.

Release of effluant water at or near the shoreline except at high Flver flow rates could cause 100 Ares drlniking water to exceed theso criteris and blologlcal concentration of radiolsotopes that could cause Islands of foam and algae around Rlchland boat docks to be a radiation exposure problem.

(3) A. F. Foster, "The Frfect on F1sh of Increas1ng the Temperature of the Columble RAver", Warch 14, 1950, 116-54850 (secret). 


\section{-4- HW-65733-RD}

B. Assumptions

For the purposes of forecasting the effects of proposed changes

the following assumptlons were made:

1. Both 105-105 and 105-KN operating with 1 low rates of 188,000 6rm, with a $93^{\circ}$ bulk outlet temperature limit and at $80 \%$ time operated effictency.

2. Noxmal Hyer Ilow rates of 105,000 ofm annual average, 100,000 cfs average durting August and September, 60,000 crs average dursag mintmon Flow pertods, and 36,000 crs dally minimm flow during mintmum flow pertoda.

3. Uniferm diatribution of effluent water in the mver except for constderations of 100 Area drinkdng water.

4. Consumption of whtterlah slesh at a untform sate of $0.5 \mathrm{lb} / \mathrm{veek}$ by a successiul flobarman between October 1 and the opring freshot. Flah eaught in the ricintty of Rangold.

5. Hexcavalent chromfun is ned.ther lost nor reduced to the less taxlc trivalent chromium betreen the point of Injection and the polnt of use.

\section{Fhosphorus-32}

Flgure I 11lustrates the potential body burden of phosphorus-32 under varlous operating conditions. The valldity of the extrapolation may be questionable, but it 1 s felt that these values would not be htgh by wore than 25\%. It can be seen that even the base case exceeds the criterla. Phosphorus-32 may be obtained from elther F1sh or raterfowl, but because of the large number of migrant waterforl only the

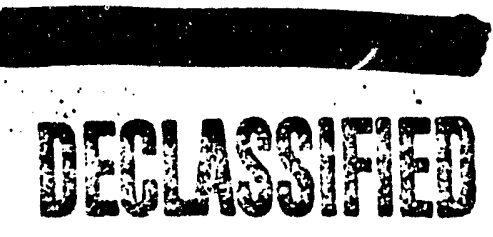


uptake from Flsh was conaldered. Perhaps 100 neople are s1gatflcantly afrected.

There are two posstble remedles for thls sttuation, nolther of which have been proven. Treatment of the effllent water by passing It over a bed of aluminum might reduce the output of phosphorus-32 by a factor of 2. Even less 18 known about the othex possibility which would be to substitute $\mathrm{CO}_{2}$ for sulfurlc acld for $\mathrm{pB}$ control. Some of the phosphorus-32 comes from the $s^{32}(n, p) p^{32}$ react1on, but the fraction that is derlved from this reaction as opposed to the $P^{31}(n, y) P^{32}$ reaction has been the subject of techntcal argument for several years.

D. Plant Drinklng Water

Hexavalent chromium in plant drlnking water may exceed the criterion for drinkeng water under present operating condstions. This forecast 18 based on the assumption that none of the hexavalent chromiun 18 lost or reduced and on an estimate of the fraction of B, C, KW, and KE efrluents that would be taken 1nto 100-D at I0W Fiver flow rates? (4) Reflelent operation of Prlest Rapids Dam will probably drop the flow rate to 36,000 cfs during the night while releasing a datly average of $60,000 \mathrm{crs}$. The reduction of hexavalent to trivalent chromium and $108 \mathrm{~s}$ of chromium in fllter plants has not been studied. Routine analyses of 100-D and 100-F drinking water have shown hexavalent chromium in concentrations slightly above the detection lintt of 0.005 ppon on a few measurements when the river Plow rate was Ior..

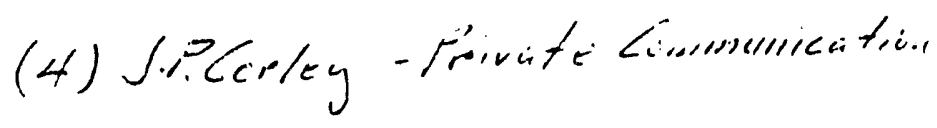

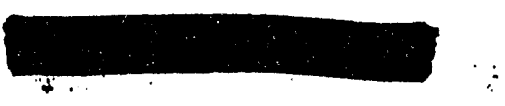


Radjologfcal limits should not be exceeded in plant drinkting water before the $11 \mathrm{mlts}$ for Ifrer water at Pasco are exceeded. Decontamination by the water treatment process by a factor of 2 or 3 and a higher IImft operstes in support of this opinfon. Iven though channeling of effluent water from upstream reactors into a downstream reactor intake could quickly use up this margin of safety, the fact that radiologtcal effects may be averaged would Insure that the bexavalent chromium linlt would be exceeded f1rst.

E. Waloactivity in River Water

Flgure 2 1llustrates the effects of varlous conditions relative to the radiological criterion for Flver contanination. The cholce of Pasco as the point of Interest does not Ignore the possibility of navigation In the rIver past the reactors, but does assume that recommended radialogtcel controls would be enforced. $(5,6)$ The method of extrapolation used has been successfully. used in the past and 18, therefore, expected to be reasonably sccurste.

F. Bexaralent Chromium in River Water

Flgure 3 illustrates the concentration of hexavelent chromfin 11s the xiver under varlous operating conditlons assuming no lose and no reduction to trivalent chromium which 18 Iess toxdc. An average river flow rate of $60,000 \mathrm{cls}$ was asaumed. SInce the deleterious effect on the Mish Is dependent upon persistance of these

(5) R. T. Jaske, et al, "grfects on Hanford Works of a Navigation Channel in the Columbla River", dated June 0, 1958, HiN-55950. (Confldent1al)

(6) R. T. Jaske, et al, same title, dated June 30, 1959, BN-55950 sup. (Confldential) 
concentrations for a month or so, and since an average flow rate of about 60,000 crs 18 required for the hydroelectrle ractlltses to meet their commitments, these curves represent the most probable condition. If 1 it is desirable to conolder the effects of lower Ilow rates, It can be done an thls graph by lowerlng the line representing the criterion by the fraction of 60,000 cfs that is being considered.

\section{G. RAver Temperature}

F1gure 4 11lustrates the theoretical temperature Increase Imediately downstream from the reactor which would result under vartinis operatiog conditi', and. Stnce the ectual temperature of the Fiver represents a belance between the forces whtch tend to Increase the temperature such as heat absorbed directly fromthe oun, return Ilow aflrrigation vater, and the operation of Intustrial facllities Including reactors, and those forces which tend to remove heat sxom the vater such as evaporation and heat transfer to the sotl, the affect of the additfonal beat added w1 II Influence the balance but will bot be felt as a simple addition to $t$ he temperature some distance domstrvam.

The deleterfous effect on the salmon run is caused by a visulents strain of becteris. The probebility of an epldeande of disease among the almon Increases vith temperature over $20^{\circ} \mathrm{C}$ and with the length of time that ouch temperatures are malintained. The river temperature at the reectors normally exceeds $20^{\circ} \mathrm{C}$ for a fen days every rear, and In 1958 epldemlc diseese was reported when temperatures between $19^{\circ}$ and $21.5^{\circ} \mathrm{C}$ persisted for nearly ton reeks.

The couplextty of the problem which 1s further aggrevated by political forces makes It 1mpossible to state a limtt on the awount 
of heat which reactors way add to the river without establlshing sinflar Iimfts on other contributors over which we have no control.

H. Rupture Products

Control of the relesse of flssion products due to fuel element ruptures would not be required in the usual case. (f) However, protection against the unusual case is indicated. Andersen, et al, in reference (8) asscuss the consenuences of fatlure of several elements In the same channel in some detall. The effects of increasing production levels on the probabllity of such an occurrence have not been evaluated. It seems unllkely that BAPO would wish to Incur the cost of decontandation and unfavorable public optnion whlch would result even though the consequences are descrlbed as belng troublescme and not (technlcally) a major hazard to Individuals in the exvirons.

(7) J. D. McCormack, I. C. Schwendtman, "Slgniflcance of Rupture Debrls in the Columbla Rtver", August 17, 1959, BW-61325 (contident1al).

(8) B. V. Andersen, et al, "Mnvlronmentel Consequences of Proposed Changes in Reactor Operat1ons", February 11, 1958, Hi-54953 (Secret). 


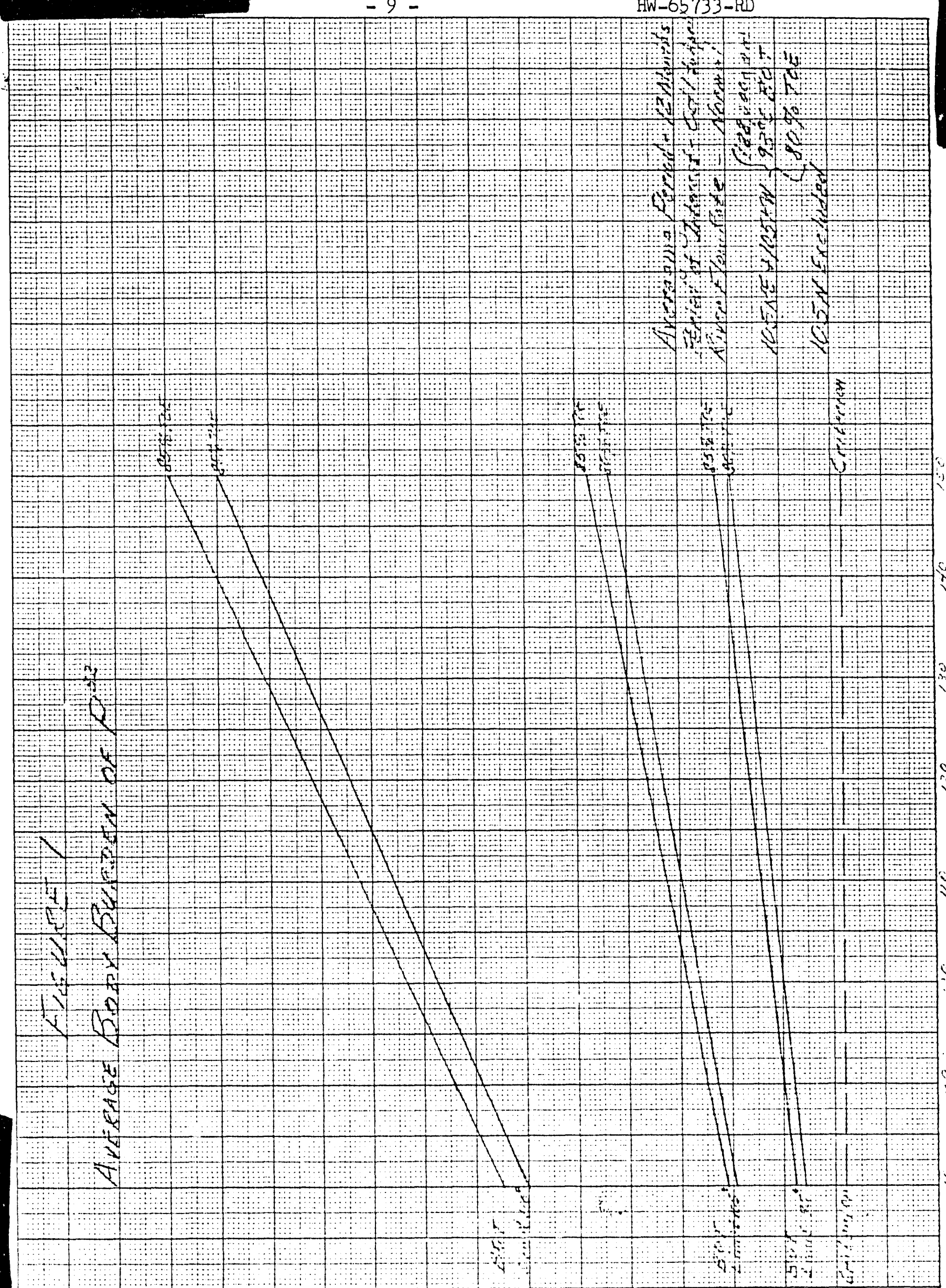

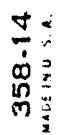

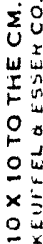




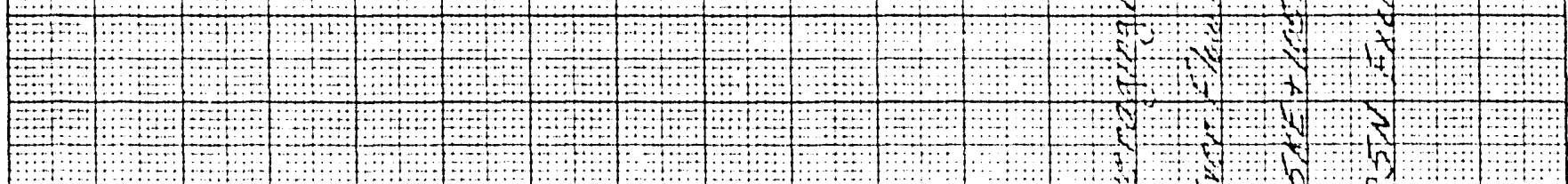

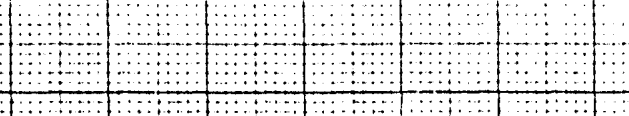
$4 \mathrm{~s}+\mathrm{y}$

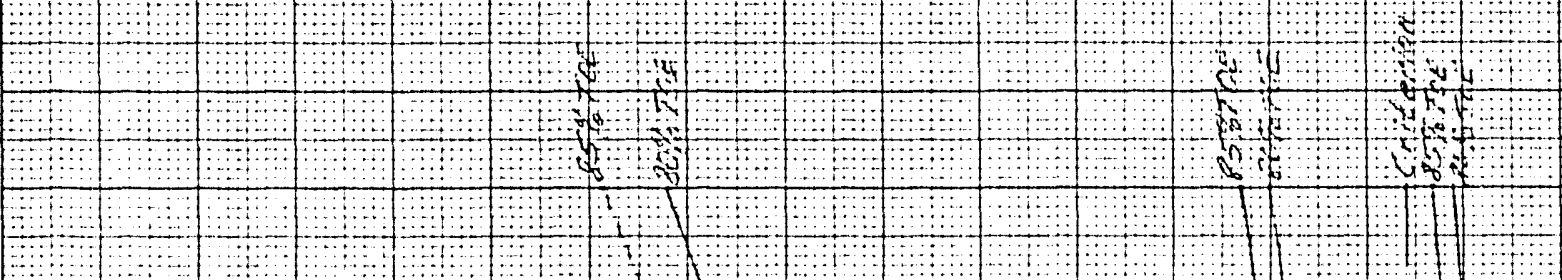

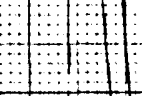




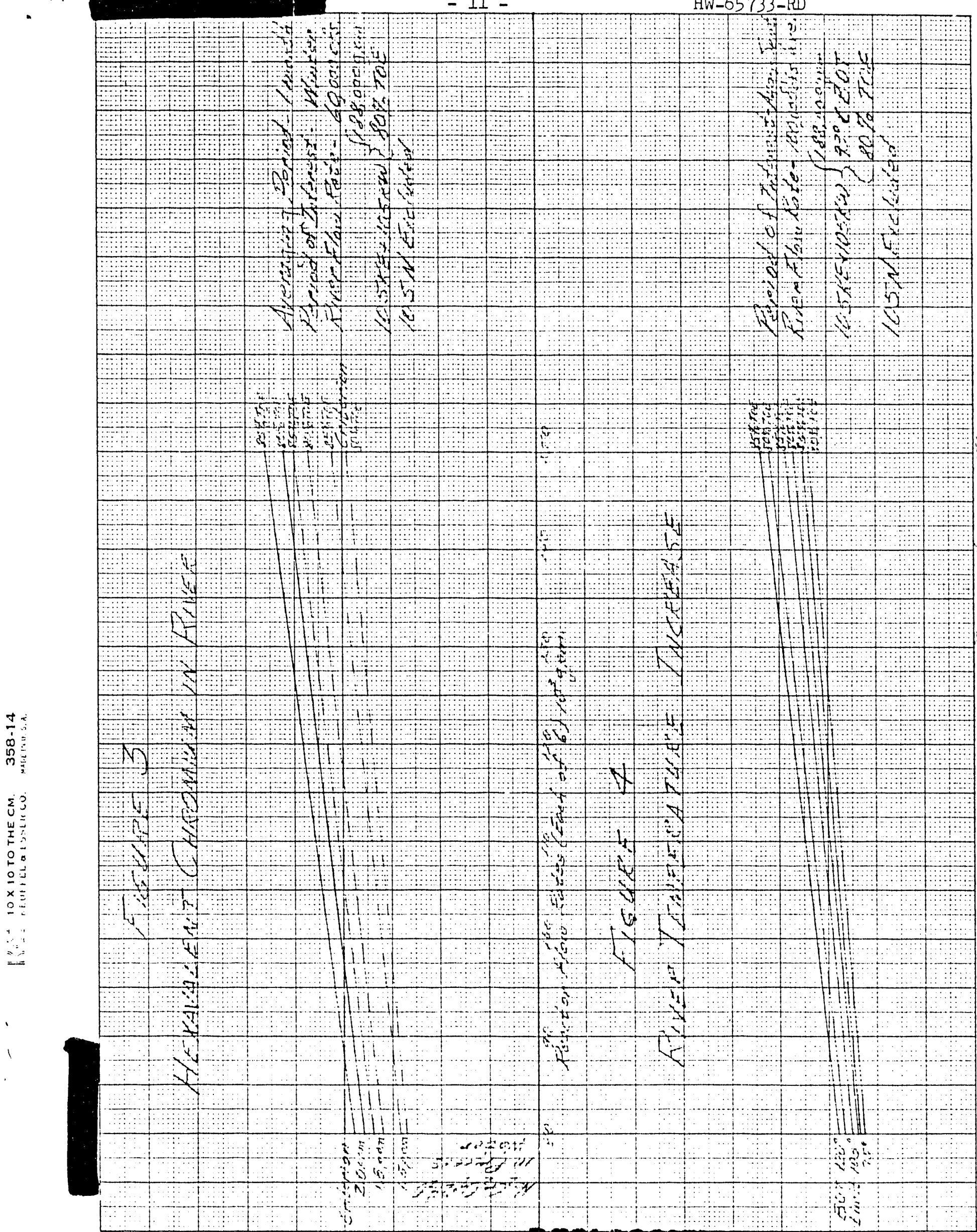




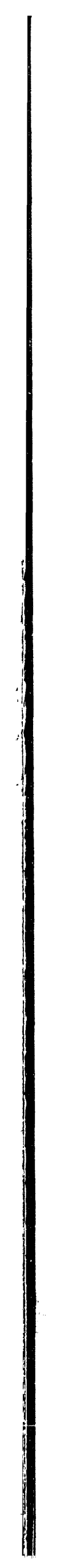

